\title{
Citrus Flatid Planthopper, Metcalfa pruinosa (Say) (Insecta: Hemiptera: Flatidae) ${ }^{1}$
}

F. W. Mead ${ }^{2}$

\section{Introduction}

True to its name, the citrus flatid planthopper, Metcalfa pruinosa (Say), is found on citrus, but also is found on a wide variety of woody plants, many of which are used in the ornamental trade. This planthopper seldom causes economic damage to most plants except to those weakened by some other factor such as freeze damage. The unsightly white, flocculent, waxy material made by the nymphs impairs the sales quality of affected plants, partly because buyers sometimes mistake these deposits for those of mealybugs or the cottony-cushion scale.

The catalogue on Flatidae by Metcalf (1957) covers the literature through 1955 and gives approximately seven pages of annotated citations to this planthopper. Previous to 1951 pruinosa (Say) was listed primarily in the genus Ormenis; however, the species was described in Flata and later referred to several times in Poeciloptera or Melormenis.

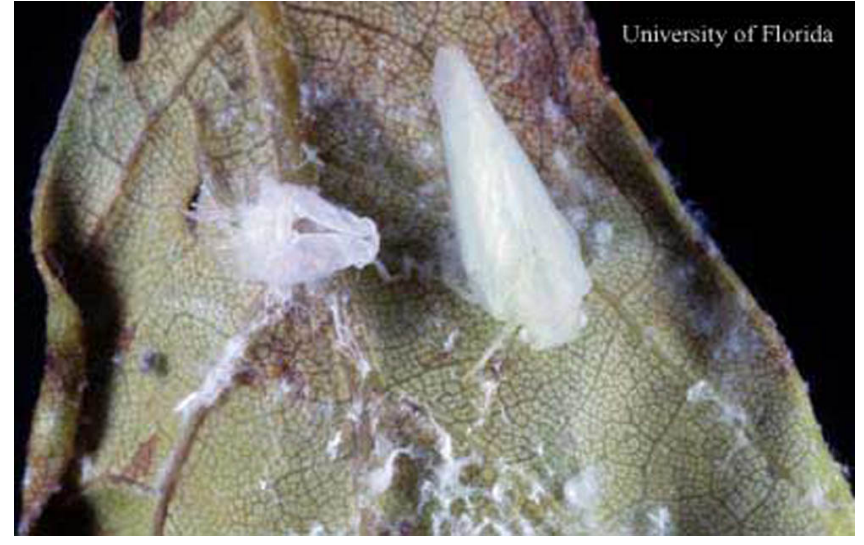

Figure 1. Newly emerged adult citrus flatid planthopper, Metcalfa pruinosa (Say). Credits: Photograph by: Lyle J. Buss, University of Florida

\section{Distribution}

M. pruinosa is common in eastern North America, ranging from Ontario and Quebec to Florida, west to the Great Plains states, south to Texas, New Mexico, Arizona, California, and Mexico. In Florida, M. pruinosa has been collected in all regions, but no specimens are at hand from the southern tip area. Metcalf and Bruner (1948) reported M. pruinosa widely distributed in Cuba.

\footnotetext{
1. This document is EENY-329 (originally published as DPI Entomology Circular 85), one of a series of Featured Creatures from the Entomology and Nematology Department, Florida Cooperative Extension Service, Institute of Food and Agricultural Sciences, University of Florida. Published: June 2004. This document is also available on Featured Creatures Website at http://creatures.ifas.ufl.edu. Please visit the EDIS Website at http://edis.ifas.ufl.edu. Additional information on these organisms, including many color photographs, is available at the Entomology and Nematology Department website at http://entnemdept.ifas.ufl.edu/.

2. F. W. Mead, Florida Department of Agriculture and Consumer Services - Division of Plant Industry, Gainesville, FL.
}

The Institute of Food and Agricultural Sciences (IFAS) is an Equal Opportunity Institution authorized to provide research, educational information and other services only to individuals and institutions that function with non-discrimination with respect to race, creed, color, religion, age, disability, sex, sexual orientation, marital status, national origin, political opinions or affiliations. U.S. Department of Agriculture, Cooperative Extension Service, University of Florida, IFAS, Florida A. \& M. University Cooperative Extension Program, and Boards of County Commissioners Cooperating. Larry Arrington, Dean 


\section{Identification}

Usually, adults of $M$. pruinosa are 5.5 to $8 \mathrm{~mm}$ in length and 2 to $3 \mathrm{~mm}$ in width at the widest point. This species, along with certain other flatids, might be mistaken for a moth at first glance. Flatids have broadly triangular front wings that are held close to the body in a vertical position and give the insects a wedge-shaped, laterally compressed appearance from above. The front wings (tegmina) have a well developed, transversely veined costal cell and a granulate clavus; the hind tibiae normally have two lateral spines in addition to those at the apex. The superficially similar acanaloniid planthoppers lack the transversely veined costal cell, granulate clavus, and the lateral spines of the hind tibiae.

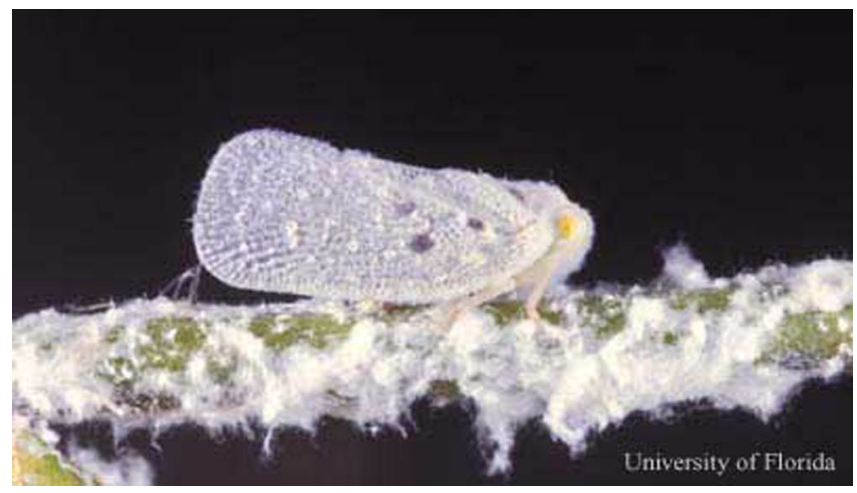

Figure 2. Adult citrus flatid planthopper, Metcalfa pruinosa (Say). Credits: Photograph by: Lyle J. Buss, University of Florida

The color of adult $M$. pruinosa varies considerably from brown to gray, due chiefly to the presence or absence of a bluish white waxy powder. A characteristic pair of dark spots is located in the basal half of each forewing.

Nymphs are less than twice as long as wide, and vary in size depending upon the growth stage. A mature nymph is approximately $4 \mathrm{~mm}$ long, not counting waxy filaments which break easily.

The following illustrations in literature may be of particular interest: genitalia drawings of $M$. pruinosa are in Metcalf and Bruner (1948); habitus and genitalia drawings in Osborn (1938); a color profile drawing of the adult in Metcalf (1923); egg puncture and adult photographs in Dozier (1928); infestation on grapefruit photograph in Wene (1950);

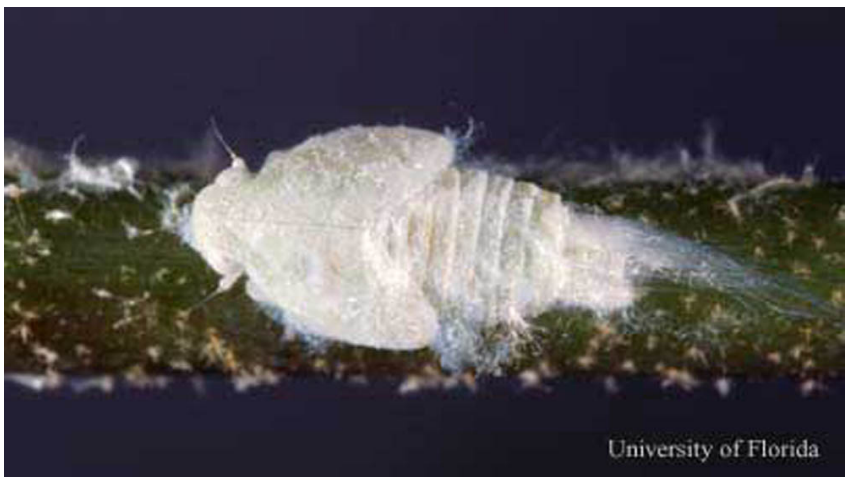

Figure 3. Nymph of the citrus flatid planthopper, Metcalfa pruinosa (Say). Credits: Photograph by: Lyle J. Buss, University of Florida

eggs, young nymphs, mature nymphs, and adult photographs in Dean and Bailey (1961).

\section{Life History}

Dean and Bailey (1961) reported on the life history of this planthopper in the Lower Rio Grande Valley and summarized the findings of previous workers. M. pruinosa overwinters in the egg stage, with hatching starting early in March in the Weslaco, Texas, area. First adults in the field were taken 69 days after the hatching date. Greater numbers were taken in June than in later months. Only one generation was observed each year. Eggs were found scattered singly in the bark of dead citrus twigs. Adults apparently can live several weeks. In Florida, the Division of Plant Industry has records of nymphs from April to June and adult records from May to October. In the Niagara peninsula, Ontario, Canada, nymphs were reported in sour cherry orchards from May to late July, and adults from late July to September.

\section{Detection}

In Florida adults have been taken repeatedly in Steiner traps and in black-light traps. The presence of this planthopper is revealed by the long, curled filaments of waxy exudate on the undersides of succulent leaves or on the terminals of branches. This woolly material often obscures the nymph producing it.

The whitish, comparatively flat planthopper can be separated easily from sedate mealybugs and cottony-cushion scales by placing a pencil point at the 
caudal end; the planthopper will jump like a leafhopper nymph. Leafhoppers do not surround themselves with flocculent exudate and have one or more rows of small spines extending the length of hind tibiae; planthoppers have only a few stout spines on hind tibiae.

The planthopper antennae arise on the side of the head beneath the eyes, instead of the front of head between the eyes, as on treehoppers, spittlebugs, leafhoppers and cicadas. No identification keys exist whereby the citrus flatid planthopper nymphs can be separated from its near relatives, but circumstantial evidence is often sufficient to permit tentative determinations. Not only are identification manuals apparently rare or non-existent on planthopper nymphs at the specific and generic levels, but they are inadequate at the family level.

M. pruinosa is the only member of its genus reported in the United States and is the only U.S. flatid of its general shape and size that has the basic dark color. The more closely related flatids usually are greenish. Outside of the U.S., particularly in Cuba, there are several species which might be confused with M. pruinosa. A subspecies, Metcalfa pruinosa cubana (Metcalf and Bruner), is listed for Cuba. The writer has not examined this subspecies nor other pertinent Antillean material.

\section{Economic Importance}

M. purinosa ordinarily does very little damage to plants; however Wene (1950) found it destroying very small buds in a lime grove which had been defoliated by a recent freeze in the Mission, Texas, area. Furthermore there was a considerable amount of fruit drop in a few heavily infested groves freeze-damaged three months previously. Wene and Riherd (1953) reported pruinosa destroying part of a hedge of Amour River privet, Ligustrum amurense, near Donna, Texas. Sooty-mold fungus commonly develops in the honeydew excreted by the citrus flatid. Limited virus transmission tests have shown $M$. pruinosa a nonvector of tristeza, peach yellows, and blueberry stunt. Apparently, it is rare for flatids to transmit virus diseases. However, it is of possible interest to the citrus industry that an Asiatic flatid,
Geisha distinctissima (Wlk.) is the vector of a virus which causes dwarf disease of satsuma orange in Japan.

\section{Management}

Usually no chemical control measures are necessary.

A dryinid wasp parasite, Psilodryinus typhlocybae (Ashmead), has been reported as common on nymphs of the citrus flatid planthopper and its relatives.

\section{Selected References}

Dean HA, Bailey JC. 1961. A flatid planthopper, Metcalfa pruinosa. Journal of Economic Entomology 54: 1104-1106.

Dozier HL. 1928. The Fulgoridae or plant-hoppers of Mississippi, including those of possible occurrence; a taxonomic, biological, ecological, and economic study. Technical Bulletin of the Mississippi Agricultural Experiment Station 14: 112-114.

Metcalf ZP. 1923. J. Elisha Mitchell Science Society 38: 152 .

Metcalf ZP. 1957. General Catalog Homoptera, Fasc. 4, Part 13, Flatidae and Hypochthonellidae, 342-350.

Metcalf ZP, Bruner SC. 1948. Cuban Flatidae with new species from adjacent regions. Annals of the Entomological Society of America 41: 96.

Osborn, H. 1938. The Fulgoridae of Ohio. Bulletin of the Ohio Biological Survey 6: 318.

Wene GP. 1950. The citrus fulgorid. Annual Proceedings of the Lower Rio Grande Valley Citrus and Vegetable Institute 4: 90-93.

Wene GP, Riherd PT. 1954. Control of puss caterpillar and fulgorids attacking ornamentals during 1953. Texas Avocado Society Year Book for 1953 : 45-46. 